\title{
A Study of Customer Loyalty towards Yoga Marketing Relationship in the Indian Urban Market
}

Neha Kawari*

\begin{abstract}
This paper examines the popular culture of Yoga and aims to shed light on the theoretical understanding of relationship marketing and its main components that have a direct or indirect impact on any relational approach. Marketing through spirituality has become a significant topic of discussion as it affects the consumption behaviour of people. Therefore, spiritual organisations are launching and selling their own products for the customers to capture the market. Here, in this study, Yoga and 'Pranayam' are considered dimensions of spirituality. It is observed that people rely on a spiritual guru for performing Yoga and Pranayam. This research was done for the city of Hubballi with 150 respondents from Yoga organisations, studios as well as people practising it. Results show that flexibility and removing stress were the major benefits from Yoga marketing.
\end{abstract}

Keywords: Relationship marketing, Yoga marketing, Effective promotional tools, Customer loyalty, Indian urban market

\section{Introduction}

Yoga marketing has a great impact on youth, elders, and all the education institutions following Yoga practices along with

* Global Business School, Hubballi, Karnataka, India;

nehakawari89@gmail.com 
exercises. Yoga helps in healthy living and is a universal means for self-implementation (Kumar, Jain, Rahman \& Jain, 2014). Yoga specifications matter more to people who are conscious of their health as well as their beauty. Patanjali played a very important role in coming up with Yoga marketing (Cowans, 2016).

Yoga is a Sanskrit word signifying union- the merging of the microcosm of our existence in our body with the macrocosm. This also implies the fusion of embodied consciousness with cosmic consciousness. The famous Yoga exponent, sage Patanjali defines Yoga as "the inhibition of psychic modifications" that ultimately results in the fission of Prakriti and Purusha. The next famous ancient text of Yoga, Shrimad Bhagvat Geeta defines Yoga as "a state of mental equanimity at each moment of the life" (Kumar, Jain, Rahman \& Jain, 2014).

\subsection{Relationship marketing}

Relationship marketing has been the subject of several research papers and studies since Berry's article in 1983. It has been defined as the attraction, maintenance, and development of a relationship with the client that aims at establishing, developing, maintaining, and strengthening the network of relationships with various stakeholders on the basis of a common objective. Besides looking into the notion of a long term relationship, variables such as trust, cooperation, commitment, relationship quality must also be looked into (Benouakrim, 2013).

\subsection{Relationship marketing variables}

Many variables and concepts traditionally used in relationship marketing were presented and defined (Benouakrim, 2013).

\subsubsection{Commitment}

Commitment is an important variable required for companies in India to ascertain good respectful relationships and customer loyalty. 


\subsubsection{Trust}

Trust is a beautiful bond which once created, cannot be denied. Winning the trust of customers would ensure loyalty towards their products and in their services.

\subsubsection{Satisfaction of the relationship}

Satisfaction is also equally important in maintaining good relationships with customers where they have a positive influence towards the company and the services being provided. It is believed that "More satisfaction leads to more loyal customers".

\subsubsection{Relationship quality}

Relationship quality is believed to be the most powerful marketing tool. It also helps in improving and maintaining present customers rather than attracting new customers.

\subsection{Current market situation}

The Global Yoga market is worth $\$ 80$ billion. In India, this market is worth Rs 490 billion. Almost $40 \%$ of this comes from service. The rest of it is a market of Yoga products and accessories such as Yoga mats and so on. The factors that have given a boost to the Yoga industry in India are International Yoga Day, stressed lifestyle, yoga trainers, and yoga communities to name a few.

\section{Literature review}

Relationship marketing plays an important role in building trust and maintaining a good bond (Benouakrim, 2013). In the article, "Relationship marketing", the author talks about how this specific type of marketing facilitates the relationships with customers and also develops an understanding of how it works in urban marketing in building the loyalty and bringing profits to the company.

Spirituality has been argued to be an important dimension of marketing (Kumar, Jain, Rahman \& Jain, 2014). The article, "Marketing through spirituality: A case of Patanjali Yogpeeth" highlights the importance of spirituality. The review highlights the connection between the current market trends, needs, and 
demands of customers and health. This was seen as a strategy to build a relationship with the customers through Yoga marketing.

Yoga uses social networking sites to market its uses (Cowans, 2016). In the article, "Yoga On Instagram: Disseminating or Destroying Traditional Yogic Principles?", the author argues how yoga marketing uses social networking like Instagram (with more than 300 million accounts) to virtually share their favourite poses, sequences, and Yogic philosophies. However, the author observed that while some of the themes of Yoga reflected elements of traditional Yogic principles, others did not.

Yoga is believed to reduce stress and increase energy in individuals (Rudra \& Bhandari, 2013). In the article, "Implications of Corporate Yoga: A Review", the author throws light on how Yoga removes stress and increases energy in workplaces thereby boosting productivity of corporate Yoga and lowering employee absenteeism. This explains why many of the premium corporate companies and IT parks in India follow Yoga marketing at their workplace.

\section{Need for the study}

Though customer loyalty leads to the development of the company, they take a lot of interest in the concepts of Yoga and relationship building attributes. The Yoga organisations need to understand customer behaviour towards Yoga Marketing and their loyalty towards the brand which determines the success of the company. This study focusses on the factors of customer loyalty in Yoga marketing in the Urban Indian Market. It aims at getting reliable and valid results that would help companies in planning their future activities and marketing strategies.

\section{Objectives}

- To study the customer loyalty among Yoga specifications

- To study the impact of relationship marketing in understanding customers' perception towards the concept of Yoga 
Neha Kawari Customer Loyalty towards Yoga Marketing Relationship

- To study the relationship-building process on customer loyalty in the context of Yoga Marketing

\section{Research methodology}

The study was exploratory and descriptive in nature. It was conducted on 200 residents from the city of Hubballi (urban). The research used a non-probabilistic and convenient sampling method. The tools used for analysis were SPSS and Excel. The data was collected using a questionnaire.

\subsection{Data analysis and interpretation}

Table 1 Descriptive analysis

\begin{tabular}{|c|c|c|}
\hline Gender & Frequency & Percent \\
\hline Male & 75 & 50.0 \\
\hline Female & 75 & 50.0 \\
\hline Total & 150 & 100.0 \\
\hline Have you practised Yoga before? & Frequency & Percent \\
\hline Yes & 98 & 65.3 \\
\hline No & 52 & 34.7 \\
\hline Total & 150 & 100.0 \\
\hline Age Group : & Frequency & Percent \\
\hline $18-26$ & 50 & 33.3 \\
\hline $27-35$ & 53 & 35.3 \\
\hline 35 and more & 47 & 31.3 \\
\hline Total & 150 & 100.0 \\
\hline
\end{tabular}

Table 2 Factor analysis of "From Yoga, I want to gain?"; Gender wise

\begin{tabular}{|c|c|c|c|c|c|c|}
\hline & \multicolumn{4}{|c|}{ Male } & \multirow{2}{*}{\multicolumn{2}{|c|}{$\begin{array}{c}\text { Female } \\
\text { Component }\end{array}$}} \\
\hline Rotated & & Com & nent & & & \\
\hline $\begin{array}{l}\text { Component } \\
\text { Matrix }\end{array}$ & 1 & 2 & 3 & 4 & 1 & 2 \\
\hline $\begin{array}{l}\text { Better vitality } \\
\text { concentration }\end{array}$ & 0.939 & -0.114 & 0.249 & -0.154 & -0.321 & -0.746 \\
\hline Flexibility & -0.028 & 0.974 & 0.143 & -0.124 & 0.803 & -0.233 \\
\hline Removing stress & -0.674 & -0.466 & 0.419 & -0.36 & -0.244 & 0.834 \\
\hline Relaxation mood & -0.129 & -0.142 & -0.957 & -0.166 & -0.668 & -0.035 \\
\hline Meditation & -0.053 & -0.107 & 0.147 & 0.975 & 0.589 & 0.181 \\
\hline
\end{tabular}


Male respondents from Yoga have ranked Better Vitality Concentration as their $1^{\text {st }}$ preference and have given least importance to Flexibility. Flexibility, on the other hand has been ranked as the first preference by the female respondents. Flexibility and Removing Stress are mostly preferred by both male and female respondents.

Table 3 Factor analysis of "From Yoga, I want to gain?"; Age group

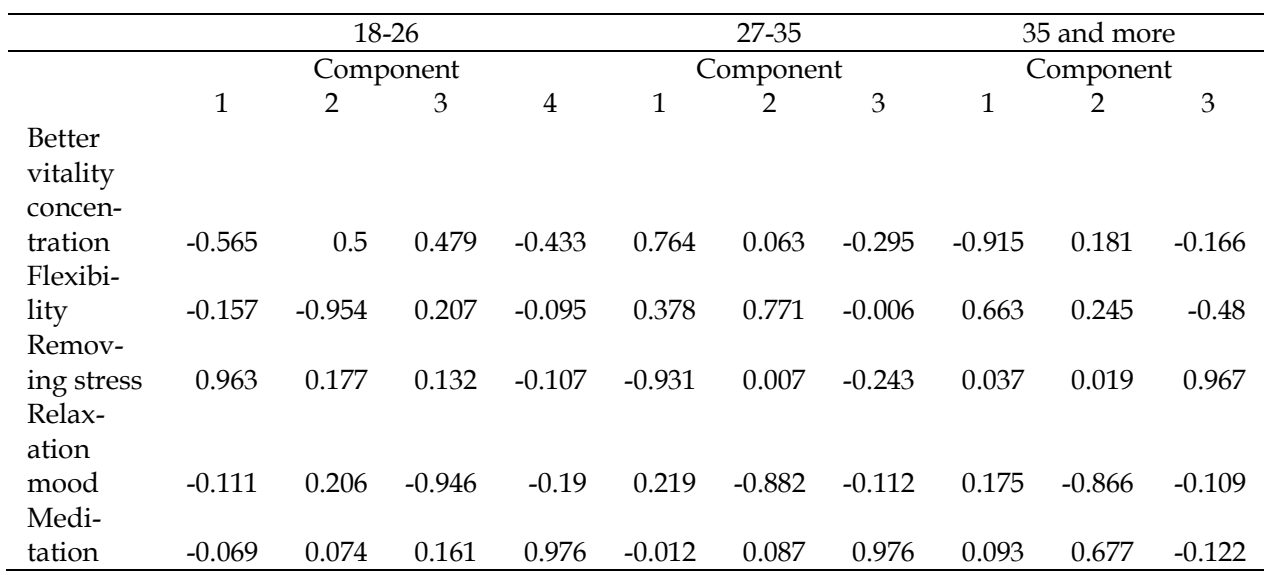

The respondents of Yoga from the age group 18-26 have ranked Removing Stress as their $1^{\text {st }}$ preference. But, respondents between the age group of 27-35 ranked Better Vitality Concentration as their $1^{\text {st }}$ preference and respondents aged more than 35 ranked Flexibility as their $1^{\text {st }}$ preference.

Table 04: Factor analysis of "From Yoga, I want to gain"; "how well do I know about Yoga marketing?"

\begin{tabular}{|c|c|c|c|c|c|c|c|c|c|c|c|}
\hline & \multirow{2}{*}{\multicolumn{2}{|c|}{$\begin{array}{c}\text { Street } \\
\text { Medicines }\end{array}$}} & \multicolumn{3}{|c|}{ Spiritual Leaders } & \multicolumn{3}{|c|}{ Yoga Organisations } & \multicolumn{3}{|c|}{ Yoga through Patanjali } \\
\hline & & & & mponen & & & mpone & & & mpones & \\
\hline & 1 & 2 & 1 & 2 & 3 & 1 & 2 & 3 & 1 & 2 & 3 \\
\hline $\begin{array}{l}\text { Better } \\
\text { vitality } \\
\text { concen- } \\
\text { tration }\end{array}$ & -0.772 & 0.156 & 0.196 & -0.848 & -0.228 & 0.116 & 0.105 & -0.945 & 0.721 & 0.057 & 0.128 \\
\hline $\begin{array}{l}\text { Flexibi- } \\
\text { lity }\end{array}$ & -0.611 & -0.063 & 0.747 & 0.23 & -0.205 & 0.737 & 0.273 & 0.119 & 0.133 & -0.916 & -0.191 \\
\hline $\begin{array}{l}\text { Remov- } \\
\text { ing stress }\end{array}$ & 0.838 & 0.079 & -0.851 & 0.283 & -0.16 & -0.898 & 0.14 & 0.22 & -0.919 & 0.103 & 0.024 \\
\hline $\begin{array}{l}\text { Relaxa- } \\
\text { tion } \\
\text { mood }\end{array}$ & 0.285 & -0.811 & -0.021 & 0.063 & 0.959 & 0.033 & -0.915 & 0.268 & 0.206 & 0.668 & -0.552 \\
\hline $\begin{array}{l}\text { Medita- } \\
\text { tion }\end{array}$ & 0.298 & 0.758 & 0.4 & 0.61 & -0.274 & 0.232 & 0.587 & 0.421 & 0.161 & 0.093 & 0.877 \\
\hline
\end{tabular}


Respondents who know about Yoga Marketing through Spiritual Leaders want to gain Flexibility as their 1stpreference while the ones who know about it through spiritual leaders have marked Flexibility as their 1 stpreference. Also, respondents who know about Yoga marketing through Yoga organisations have ranked Flexibility as their 1stpreference and respondents who know about Yoga Marketing through Patanjali have ranked Better Vitality Concentration as their $1^{\text {st }}$ preference.

Table 5 Factor analysis of "How frequently do you shop Yoga related products?"; "Reasons why I prefer Yoga"

\begin{tabular}{|c|c|c|c|c|c|c|c|c|c|c|}
\hline & \multicolumn{2}{|c|}{ Every week } & \multicolumn{3}{|c|}{ Once in 2 weeks } & \multicolumn{3}{|c|}{ Once in 3 weeks } & \multicolumn{2}{|c|}{ Once in a month } \\
\hline & \multicolumn{2}{|c|}{ Component } & \multicolumn{3}{|c|}{ Component } & \multicolumn{3}{|c|}{ Component } & \multicolumn{2}{|c|}{ Component } \\
\hline & 1 & 2 & 1 & 2 & 3 & 1 & 2 & 3 & 1 & 2 \\
\hline Fitness & 0.299 & -0.834 & 0.104 & -0.153 & 0.971 & 0.361 & 0.681 & -0.622 & -0.02 & 0.691 \\
\hline $\begin{array}{l}\text { Lose } \\
\text { weight } \\
\text { Cure }\end{array}$ & 0.761 & 0.095 & -0.916 & -0.29 & -0.219 & 0.668 & -0.036 & 0.732 & -0.02 & 0.691 \\
\hline $\begin{array}{l}\text { Disease } \\
\text { Healthy }\end{array}$ & 0.289 & 0.734 & 0.678 & -0.498 & -0.514 & -0.893 & 0.289 & 0.313 & -0.743 & -0.579 \\
\hline Living & -0.953 & 0.111 & 0.148 & 0.963 & -0.153 & -0.039 & -0.906 & -0.397 & 0.928 & -0.248 \\
\hline
\end{tabular}

Respondents who shop for Yoga related products every week are the ones who want to Lose weight as their $1{ }^{\text {st }}$ preference while the ones who shop once in 2 weeks want to Cure Disease as their $1^{\text {st }}$ preference. Moving on, respondents shopping once in three weeks are the ones who want to Lose Weight as their $1^{\text {st }}$ preference and people shopping once in a month are the ones who have marked Healthy Living as their 1 stpreference for doing Yoga.

Table 6 Descriptive analysis about "what comes to your mind when you think about Yoga Marketing?"

\begin{tabular}{|c|c|c|}
\hline Better Services & Frequency & Percent \\
\hline No response & 72 & 48.0 \\
\hline Response & 78 & 52.0 \\
\hline Total & 150 & 100.0 \\
\hline Good Health Facilities & Frequency & Percent \\
\hline No response & 68 & 45.3 \\
\hline Response & 82 & 54.7 \\
\hline Total & 150 & 100.0 \\
\hline Balanced Diet & Frequency & Percent \\
\hline No response & 61 & 40.7 \\
\hline Response & 89 & 59.3 \\
\hline Total & 150 & 100.0 \\
\hline
\end{tabular}


Table 7 Descriptive analysis of responses regarding whether building a relationship with the customers are given value in Yoga marketing

\begin{tabular}{|c|c|c|}
\hline $\begin{array}{l}\text { Relationship building with the } \\
\text { customers are given great value in Yoga } \\
\text { marketing }\end{array}$ & Frequency & Percent \\
\hline Agree & 98 & 65.3 \\
\hline Can't say & 19 & 12.7 \\
\hline Disagree & 33 & 22.0 \\
\hline Total & 150 & 100.0 \\
\hline $\begin{array}{l}\text { Are you a loyal customer for your Yoga } \\
\text { Marketing? }\end{array}$ & Frequency & Percent \\
\hline No response & 3 & 2.0 \\
\hline Yes always & 45 & 30.0 \\
\hline Only for better services & 73 & 48.7 \\
\hline Never I keep experimenting & 29 & 19.3 \\
\hline Total & 150 & 100.0 \\
\hline
\end{tabular}

Table 8 Descriptive analysis of responses regarding Yoga Marketing being beneficial

\begin{tabular}{lrrr}
\hline $\begin{array}{l}\text { Do you prefer Yoga Marketing because } \\
\text { they are more beneficial? }\end{array}$ & Frequency & Percent \\
\hline Yes & 103 & 68.7 \\
No & 47 & 31.3 \\
Total & 150 & 100.0 \\
Are you satisfied with the present Yoga & & & \\
Marketing trends in India? & & Percent \\
Yes & Frequency & & 74.0 \\
No & 111 & & 26.0 \\
Total & 39 & 100.0 \\
\hline
\end{tabular}

\section{Findings}

According to Table 02, male respondents want to gain Better Vitality Concentration from Yoga as compared to female respondents who want to gain Flexibility from the practice. According to Table 03, respondents between the age group of 18-26 want to do Yoga to remove stress whereas respondents between the age group of 27-35 wish to gain Better Vitality Concentration through it. Furthermore, respondents aged 35 and more want to gain Flexibility from the practice. According to Table 04, respondents who know about Yoga Marketing through street 
medicines want to remove stress by doing Yoga whereas spiritual leaders want to gain Flexibility through it. Also, while, Yoga organisations focus on Flexibility through the practice, Patanjali wants to gain Better Vitality Concentration through it. According to Table 05, respondents who shop for Yoga related products every week are the ones who want to Lose Weight along with the ones who shop once in three weeks. On the other hand, respondents shopping once in two weeks want to Cure diseases through the practice. Furthermore, respondents shopping once a month prefer Healthy Living through Yoga.

\section{Conclusion}

From the research and analysis, it has been found that Yoga Marketing stands foremost in case of relationship building with the customers. Therefore it is important to come up with marketing and promotional strategies so that it becomes one of the finest leading service sectors. Besides, it is important to create Brand awareness with Yoga Marketing ideas, to learn the tactics of inbound marketing, to understand Yoga as an art of empathy, to get on board with the trends, to advertise and reach to the hearts of the customers, to socialise more and rely on different promotional activities and so on. As there are more respondents who are interested to gain different benefits from Yoga, the need to work on the health benefits increases. A tie-up with many big health beneficial institutions can be crucial for future growth as well as to work on "Yoga unique trends". In India, since there is more demand for Yoga (marketing as well as organisations), the market potential also seems more. This research will contribute to making it one of the leading service sectors in India.

\section{References}

Rudra, C.B.B., \& Bhandari, B. (2013). Implications of Corporate Yoga: A review, vol. 8. Department of Yogic sciences, University of Patanjali, Haridwar, Uttarakhand, India.

F. E. K. Hind Benouakrim. (2013). Relationship marketing, 2(10).

Kumar, V., Jain, A., Rahman, Z., \& Jain, A. (2014). Marketing through spirituality: A case of Patanjali Yogpeeth. Procedia-Social and Behavioral Sciences, 133, 481-490. 
Cowans, S. (2016). Yoga on Instagram: disseminating or destroying traditional yoga principles? Journalism Elon of Undergraduate research in Communications University, 7(1), 33-43. 